Arab Univ. J. Agric. Sci., Ain Shams Univ., Cairo, 13(3), 677 - 688, 2005

\title{
EFFECT OF INOCULATION TIMING WITH ARBUSCULAR MYCORRHIZAL FUNGI ON GROWTH AND FLOWERING OF MICROPROPAGATED Chrysanthemum morifolium
}

[44]

\author{
Attia $^{1 a}$, M. and Rawia A. Eid ${ }^{2}$
}

\begin{abstract}
A pot experiment was carried out to evaluate the effect of arbuscular mycorrhizal fungi (AMF) inoculation timing on growth and flowering of Chrysanthemum morifolium cuttings. AMF inocula were either directly applied to cutting (AMFC), or applied at transplanting stage (AMFT). The data showed: a significant difference in plant growth of AMF treatment compared with non-inoculated treatment at transplanting stage. Rooting rate in AMF treatment was $99 \%$ whereas it was $77 \%$ in non-mycorrhizal inoculated. The colonization rate was 53.9\% in AMF treatment, while no in non-AMF treatment. Tap root length and number of lateral roots in AMF treatments were twice of those recorded for non-AMF treatments. Inoculation of AMF significantly increased shoot and root growth at transplanting stage. After transplantation, chrysanthemum plants in AMFC and AMFT treatments had 76.42 and $64.24 \%$ colonization rate, respectively. Plant height, leaf area, root length, fresh and dry weight of shoots, stems and roots in AMF inoculation treatments (AMFC and AMFT) increased significantly than those of control plants. AMF inoculation significantly shortened flowering time compared with non-AMF plants. Fresh weight, width and length of flowers in AMFC and AMFT treatments were generally higher than those in control. However, a significant increase in fresh weight, width and length of flowers was found in AMFC compared with AMFT treatment. A significant increase of macronutrient concentrations in leaves was observed for AMFC treatment compared with control. Mn concentration in AMFC and AMFT was more than double of that in control. In roots, macro and micronutrient concentrations were generally higher in AMFC than AMFT or control treatments.
\end{abstract}

Key words: Chrysanthemum; Arbuscular mycorrhizal fungi; Colonization; Rooting rate

1- Agric Microbiology Dep., National Research Center, Dokki, Cairo, Egypt

2- Ornamental Plant and Woody Trees Dep., National Research Center, Dokki, Cairo, Egypt

${ }^{a}$ E mail: magdyattia@hotmail.com

(Received April 16, 2005)

(Accepted May16, 2005) 
Arab Univ. J. Agric. Sci., Ain Shams Univ., Cairo, 13(3), 677 - 688, 2005

\section{INTRODUCTION}

Micropropagated ornamental plants are often grown from cuttings in disin $\square$ fectesbils or growth media to avoid the risk of contamination and to ensure controlled conditions giving homogenous growth. However, such practice could eliminate potential pathogens as well as beneficial microorganisms. Therefore, micropropagated plants should be inoculated with beneficial microorganisms particularly symbiotic associates.

Arbuscular mycorrhizal fungi (AMF) inoculation is known to have tremendous effects on plant growth by enhancing nutrient and water uptake (Kim et al 1998; Badr El-Din and Attia 2003), inducing changes in root morphology (Azcon-Aguilar et al 1996) and providing protection to colonized roots against pathogens (Abdalla and AbdelFattah, 2000 and Attia et al 2004). Inoculation of micropropagated plants with AMF at the beginning of the acclimatization period resulted in greater plant height, leaf area and fresh weight of shoots and roots, as well as higher rate of photosynthesis and transpiration than controls (Yano-Melo et al 1999). Mycorrhizal inoculation at transplanting stage also improved growth and success in transplanting micropropagated plantlets of Sesbania sesban. Only $30 \%$ of plantlets transferred to soil without AMF survived, whereas all the plantlets inoculated with AMF survived due to greater vigor to successfully withstand transplantation shock (Subhan et al 1998). Monticelli et al (2000) found that micropropagated plants of Prunus genus inoculated with AMF showed increases in plant height; shoot dry weight, and root diameter compared with control plants.

Moreover, mycorrhizal inoculation at the early weaning phase resulted in better plant growth compared with that at the transplanting phase, 1 month after the start of acclimatiza $\square$ tionAMF inoculation of Malus sp. before acclimatization, i.e directly at rooting phase of microcuttings did not improve rooting rate. However, microcuttings established with AMF resulted in greater shoot height than noninoculated plants throughout the growing season (Uosukainen and Vestberg, 1994).

The effect of inoculation timing on survival of cuttings, their subsequent growth, and flowering of ornamental plants seemed to be an interesting area of research and not been fully understood. Therefore, this study aimed to evaluate the effects of AMF colonization on rooting growth, flowering and nutrient concentrations of chrysanthemum at rooting and transplanting stage.

\section{MATERIAL AND METHODS}

\section{Chrysanthemum cuttings}

Cuttings of chrysanthemum

1- Agric Microbiology Dep., National Research Center, Dokki, Cairo, Egypt

2- Ornamental Plant and Woody Trees Dep., National Research Center, Dokki, Cairo, Egypt

${ }^{a} E$ mail: magdyattia@hotmail.com

(Received April 16, 2005)

(Accepted May16, 2005) 
(Chrysanthemum morifolium) were obtained from 2-years-old stock plants grown in pots under greenhouse conditions at El Kata village, Giza Governorate. Cuttings consisted of a lateral shoot with three leaves giving a length of $6 \mathrm{~cm}$ and $0.30 \mathrm{~cm}$ diameter.

\section{Arbuscular mycorrhizal fungi (AMF) inoculum}

The AMF inoculum was obtained from a pot culture of sorghum that was grown for 5 months in a mixture of peat: vermiculite: perlite mix 1:1:1 by volume and inoculated with Glomus spp. (Badr El-Din et al 1999). The inoculum was a mixture of colonized roots, hyphae, and spores (50 spores per gram).

\section{Experimental technique}

To evaluate the effects of AMF inoculation timing on growth of cuttings, two treatments and one control were made. A 150 out of 450 cuttings were directly inoculated with AMF by placing them into holes contained $2 \mathrm{~g}$ of inoculum in a sterile medium (vermiculite : sand $=1: 1, \mathrm{v} / \mathrm{v})$ on a nursery bed $(0.5 \mathrm{ml}$ x $0.5 \mathrm{~mW}$ x $0.1 \mathrm{mH}$ ). The other 300 cuttings were raised in the bed without AMF inoculation. Each nursery bed received 50 cuttings at spacing of $6 \mathrm{~cm}$ and then placed on a bench in a greenhouse with a completely randomized design. The cuttings were grown for 1 month in $14 \mathrm{~h}$ light at $30^{\circ} \mathrm{C}$ and $10 \mathrm{~h}$ dark at $20^{\circ} \mathrm{C}$ and fed with a half strength of Hoagland's solution (Hoagland and Arnon, 1938). After 1 month (transplanted stage), 100 plantlets with medium size of those directly inoculated with AMF were transplanted in to a tray $(3.45 \mathrm{ml} \times 0.66 \mathrm{~mW} \times 0.15 \mathrm{mH})$ filled with a non-sterile PP medium (perlite : peat 1:1, v/v) (AMFC). Two hundred plantlets with medium size out of the uninoculated 300 plantlets were selected and transplanted into the PP medium. One hundred out from 200 plantlets were inoculated with $2 \mathrm{~g}$ of AMF inoculum (AMFT); while, 100 plantlets did not receive AMF inoculum (control). Each tray had 20 plantlets at spacing of $30 \mathrm{~cm}$ placed on a greenhouse bench in a completely randomized design. The medium used was enriched by adding superphosphate $\left(15.5 \% \mathrm{P}_{2} \mathrm{O}_{5}\right)$, ammonium nitrate $(33.5 \% \mathrm{~N})$ plus potassium sulphate $\left(48 \% \mathrm{~K}_{2} \mathrm{O}\right)$ by the rate of 50,300 and $150 \mathrm{~g} / 1200 \mathrm{~L}$, respectively.

After transplanting, plantlets of chrysanthemum were grown for 16 weeks in $14 \mathrm{~h}$ light at $28^{\circ} \mathrm{C}$ for and in $10 \mathrm{~h}$ dark at $20^{\circ} \mathrm{C}$. The plantlets were fed with a nutrient solution $\left(\mathrm{KNO}_{3} 2 \mathrm{mM}\right.$, $\mathrm{NH}_{4} \mathrm{H}_{2} \mathrm{PO}_{4} 0.33 \mathrm{mM}, \mathrm{MgSO}_{4} .7 \mathrm{H}_{2} \mathrm{O} 0.5$ $\mathrm{mM}$, Fe-EDTA $0.022 \mathrm{mM}$, $\mathrm{Ca}\left(\mathrm{NO}_{3}\right)_{2} \cdot 4 \mathrm{H}_{2} \mathrm{O} 1 \mathrm{mM}, \mathrm{MnSO}_{4} .5 \mathrm{H}_{2} \mathrm{O}$ $0.33 \mathrm{mM}, \mathrm{H}_{3} \mathrm{PO}_{3} 2.36 \mathrm{mM}$, $\mathrm{ZnSO}_{4} .4 \mathrm{H}_{2} \mathrm{O} .7 \mathrm{H}_{2} \mathrm{O} 0.035 \mathrm{mM}$, $\mathrm{CuSO}_{4} .5 \mathrm{H}_{2} \mathrm{O} 0.02 \mathrm{mM},\left(\mathrm{NH}_{4}\right)_{6} \mathrm{Mo}_{7} \mathrm{O}_{24}$ $0.0013 \mathrm{mM}$ ) for 4 weeks, and 1.5 strength of the nutrient solution for the rest of growing period.

At transplanting stage, rooting rate and early growth response of plantlets from AMF inoculation and non-AMF inoculation treatments were measured. After transplanting plant growth, colonization rate and flowering characteristics were examined.

\section{Plant analysis}

Mycorrhizal colonization of 
chrysanthemum roots was determined by the magnified intersect method described by McGonigle et al (1990). The roots of chrysanthemum plants were collected at transplanting stage (1 month) and after transplanting plant growth (100 days after transplanting). Fresh roots were thourghly washed with water and then cut into $1 \mathrm{~cm}$ segments. Roots were placed into $20 \mathrm{ml}$ vials containing $10 \% \mathrm{KOH}$ solution. The vials with root samples were kept for $1 \mathrm{~h}$ at $90^{\circ} \mathrm{C}$ and then washed with water and stained with Chlorazol black E and held at $50^{\circ} \mathrm{C}$ overnight. Roots were then washed with water and glycerin until clearing stage. Root colonization percentage was determined by dividing the number of colonized roots by the total number of examined root segments

\section{McGonigle et al (1990).}

Fresh and dry weight of leaf, stem and root were recorded. A $0.5 \mathrm{~g}$ finely ground shoot was placed in a $100 \mathrm{ml}$ microkjeldahl flask with $10 \mathrm{ml}$ concentrated $\mathrm{H}_{2} \mathrm{SO}_{4}$. A $0.5 \mathrm{ml} \mathrm{H}_{2} \mathrm{O}_{2}$ was added to the sample every $10 \mathrm{~min}$ for 90 min (total $4.5 \mathrm{ml}$ ). After cooling, the solution was filtered through Whatman no. 6 filter paper into $100 \mathrm{ml}$ flasks. Macro and micronutrient concentrations were assayed by the method of Jones $\boldsymbol{e t}$ al (1991). Rooting rate was calculated by dividing the number of survival cuttings by the total number of cuttings planted. Flowers were counted in each treatment for 100 days after transplanting. For flower characteristics, total flower fresh weight, number of flower, flower length, and width were examined.

\section{Statistical analysis}

Analysis of variance was performed using the SAS version 6.08 (SAS
Institute, 1990). The least significant difference (LSD) among mean values was calculated at $\mathrm{P}=0: 05$ or 0.01 confidence level.

\section{RESULTS}

\section{Colonization of arbuscular mycorrhizal fungi}

Before transplanting, cuttings inoculation with mycorrhizal fungi were well colonized. Colonization root of AMF rate was $53.9 \%$ in AMF treatment, while no colonization was observed in non-AMF treatments. After transplanting, AMFC treatments, chrysanthemum plants showed $76.42 \%$ colonization rate, while mycorrhizal plants in AMFT scored $64.24 \%$ colonization rate (Table, 1). There was a $12.18 \%$ increase in colonization rate in AMFC compared to AMFT. Hyphal colonization was consistently quite high, and considerable numbers of vesicles formed in all roots. Arbuscular colonization was very high in AMFT and low in AMFC.

\section{Plant growth as influenced by AMF inoculation at cutting stage}

Data presented in Table (2) showed that, at transplanting stage, AMF treatment had significant affect on growth characters of the cuttings compared with control treatment. The inoculated cuttings produced greater length plants than of the control treatments. Rooting rate was $77 \%$ in non-mycorrhizal treatment, whereas it reached to $99 \%$ in AMF treatment (Table 2). Tap root length and number of lateral roots in AMF treatment increased to more than twice of those in non-AMF treatment. Fresh weight of plants showed insignificant differences among both inoculated and uninoculated treatments. 
681

Inoculation effect with arbuscular mycorrhizal fungi on chrysanthemum

However, fresh and dry weight of root significantly increased in response to AMF inoculated treatments.

\section{Plant growth by AMF inoculation after transplanting}

Data presented in Table (3) show that, AMF had a statistical significant effect on plant height, leaf area, while root length did not affected significantly by inoculation with AMFC. Number of leaves also increased with inoculated with AMFC by about $20.37 \%$ over the control plants. Data also showed significant increase on fresh and dry weight of shoots, stems and roots in AMFC and AMFT inoculation treatments compared with control plants 
Arab Univ. J. Agric. Sci., Ain Shams Univ., Cairo, 13(3), 677 - 688, 2005

Table 1. AMF colonization of chrysanthemum root as affected by the different timing of AMF inoculation

\begin{tabular}{|lcccc|}
\hline Inoculation timing & \multicolumn{5}{c|}{ Colonization rate (\%) } \\
\cline { 2 - 5 } & Vesicle & Hyphae & Arbuscule & Total \\
\hline \multicolumn{4}{c|}{ Before transplanting } \\
\hline Inoculated & 0 & 32.44 & 21.46 & 53.9 \\
\hline \multicolumn{5}{c}{ After transplanting } \\
\hline Control & 0.24 & 2.70 & 3.12 & 6.08 \\
AMFT & $2.12 * *$ & $35.18^{* *}$ & $26.94 * *$ & $64.24 * *$ \\
AMFC & $5.34 * *$ & $48.06 * *$ & $23.02 * *$ & $76.42 * *$ \\
LSD $(P=0: 05)$ & 1.06 & 3.47 & 9.02 & 9.21 \\
LSD $(P=0: 01)$ & 1.48 & 4.87 & 12.64 & 12.92 \\
\hline
\end{tabular}

$\mathrm{AMFT}=\mathrm{AMF}$ inoculation at transplanting stage $\mathrm{AMFC}=$ direct $\mathrm{AMF}$ inoculation to cuttings

** Significant at $1 \%$.

Table 2. Effect of AMF inoculation at transplanting stage on growth characteristics of chrysanthemum cuttings

\begin{tabular}{|cccccccc|}
\hline \multirow{6}{*}{ Treatments } & $\begin{array}{c}\text { Plant } \\
\text { height } \\
(\mathrm{cm} / \\
\text { plant })\end{array}$ & $\begin{array}{c}\text { No. of } \\
\text { lateral } \\
\text { roots } \\
\text { (plant) }\end{array}$ & $\begin{array}{c}\text { Tap root } \\
\text { length } \\
(\mathrm{cm})\end{array}$ & $\begin{array}{c}\text { Rooting } \\
\text { rate } \\
(\%)\end{array}$ & $\begin{array}{c}\text { Fresh weight } \\
(\mathrm{g} / \text { plant })\end{array}$ & $\begin{array}{c}\text { Dry weight } \\
(\mathrm{g} / \text { plant })\end{array}$ \\
\cline { 5 - 7 } & & & Shoot & Root & Shoot Root \\
\hline
\end{tabular}

1- Agric Microbiology Dep., National Research Center, Dokki, Cairo, Egypt

2- Ornamental Plant and Woody Trees Dep., National Research Center, Dokki, Cairo, Egypt

${ }^{a}$ E mail: magdyattia@hotmail.com

(Received April 16, 2005)

(Accepted May16, 2005) 
Inoculation effect with arbuscular mycorrhizal fungi on chrysanthemum

* Significant at $5 \% . \quad * *$ Significant at $1 \%$.

Arab Univ. J. Agric. Sci., 13(3), 2005 
Arab Univ. J. Agric. Sci., Ain Shams Univ., Cairo, 13(3), 677 - 688, 2005

1- Agric Microbiology Dep., National Research Center, Dokki, Cairo, Egypt

2- Ornamental Plant and Woody Trees Dep., National Research Center, Dokki, Cairo, Egypt

${ }^{a}$ E mail: magdyattia@hotmail.com

(Received April 16, 2005)

(Accepted May16, 2005) 
(Table, 3). However, AMFC treatments gave insignificantly greater fresh weight of leaves, stem and root than those obtained by AMFT. The highest increase in plant growth was observed in AMFC treatment. Dry weight of leaves and stems were higher for cutting of AMFC treatments while cutting of AMDA treatments showed significant effect on root dry weight.

\section{Flowering characteristics}

Plants inoculated with AMF flowered earlier than the uninoculated control (Fig. 1). Chrysanthemum in AMFC treatment flowered after 98 days of transplanting, whereas those grown in AMFT and control treatments needed more 6 and 14 days for flowring, respectively. Fresh weight, width and height of flowers in AMFC and AMFT treatments were generally higher than those in control treatment (Table, 4). However, significant increase in fresh weight, width and height of flowers were recorded in AMFC treatment.

\section{Nutrient concentrations}

Significant macronutrient concentrations $(\mathrm{P}, \mathrm{K}, \mathrm{Mg}$, and $\mathrm{Ca}$ ) into leaves was observed for AMFC treatments compared with control plants.

On the other hand, micro $\square$ nutrient concentrations ( $\mathrm{Mn}, \mathrm{Cu}$, and $\mathrm{Zn}$ ) was considerably increased in AMFC and AMFT treatments compared with control where Mn concentration in AMFC and AMFT treatment was more than double of that in the control. In roots, macro and micronutrient concentrations were generally higher in AMFC treatments (Table, 5). Both treatments, AMFT and
AMFC, stimulated the concentrations of mineral nutrients in both leaves and roots of dry plantlet. Data clearly show that there were no significant differences between the AMFT and control plants regarding $\mathrm{P}, \mathrm{N}, \mathrm{K}, \mathrm{M}$ and $\mathrm{Ca}$ concentrations, while, AMFT treatments showed significant effect on $\mathrm{Fe}, \mathrm{Mn}$, and $\mathrm{Cu}$ concentration.

\section{DISCUSSION}

The first objective of this study was to determine how much of the chrysanthe $\square$ mumlant roots could be colonized at cutting and transplanting stage of growth. At transplanting stage, colonization rate in plantlets inoculated with AMF was 53.9\%, whereas control plants did not show any colonization, as expected. Increased plant growth was observed in the plants inoculated with AMF. At transplanting stage, inoculation with AMF resulted in higher records of height, number of lateral roots, tap root length, and fresh as will as dry weight of shoots and roots compared with nonAMF treatment (Table, 2). After that, the highest colonization rate was observed in AMFC (76.42\%) followed by AMFT $(64.24 \%)$, and then control treatment $(6.08 \%)$ where plant growth positively affected as coloniza $\square$ tionate increased (Tables, 1 and 3). These results were similar to the finding of Kim et al (1998), who reported that plant growth, fresh and dry weight of tomato colonized with $54.4 \%$ was significantly increased compared with $28.9 \%$ colonization rate. This result could be associated with the increase of nutrient concentrations by mycorrhizal roots. As the colonization rate of roots increases, a mycorrhizal root system can explore more volume of soil 
Attia and Rawia Eid

with more easily uptake of nutrients from less soluble

Arab Univ. J. Agric. Sci., 13(3), 2005 
Arab Univ. J. Agric. Sci., Ain Shams Univ., Cairo, 13(3), 677 - 688, 2005

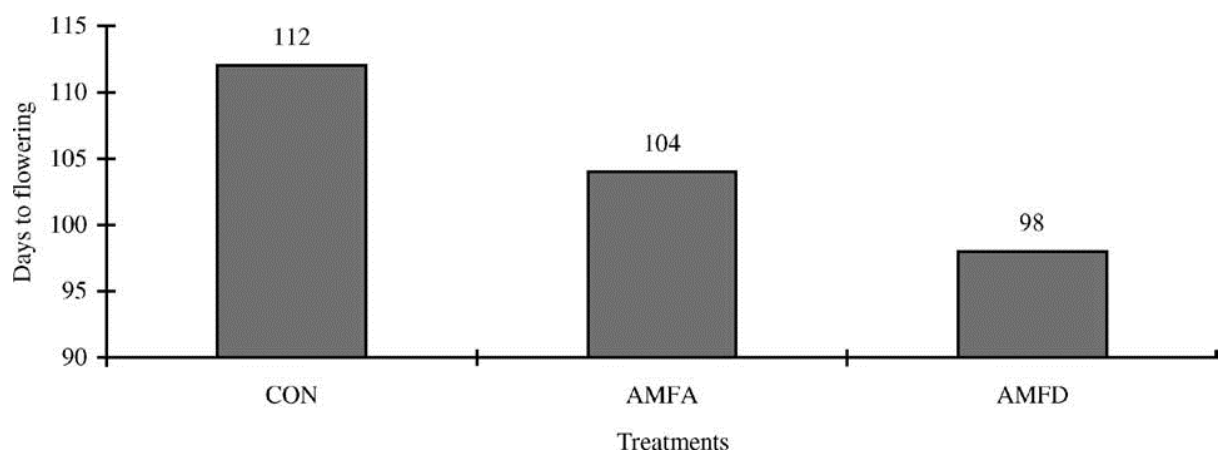

Fig. 1. Time of chrysanthemum flowering as affected by the different timing of AMF inoculation after transplanting.

$\mathrm{CON}=$ control; $\mathrm{AMFT}=\mathrm{AMF}$ inoculation at transplanting stage; $\mathrm{AMFC}=\operatorname{direct} \mathrm{AMF}$ inoculation to cuttings.

Table 4. Comparison of flowering characteristics of chrysanthemum as affected by the timing of AMF inoculation (after transplanting)

\begin{tabular}{|lccccc|}
\hline Inoculation stage & $\begin{array}{c}\text { No. of } \\
\text { floweret }\end{array}$ & $\begin{array}{c}\text { Total flower } \\
\text { fresh weight } \\
(\mathrm{g} / \text { plant })\end{array}$ & $\begin{array}{c}\text { Flower } \\
\text { width } \\
(\mathrm{cm})\end{array}$ & $\begin{array}{c}\text { Flower } \\
\text { height } \\
(\mathrm{mm})\end{array}$ & $\begin{array}{c}\text { Flower } \\
\text { stalk } \\
(\mathrm{mm})\end{array}$ \\
\hline Control & 37.4 & 14.94 & 4.90 & 13.83 & 4.63 \\
AMFT & 37.8 & $21.17 * *$ & 5.27 & 14.70 & 4.83 \\
AMFC & 41.2 & $22.82^{* *}$ & $5.93 * *$ & $15.13 *$ & 5.63 \\
LSD $(P=0: 05)$ & 5.9 & 3.80 & 0.38 & 0.96 & 1.91 \\
\hline
\end{tabular}

1- Agric Microbiology Dep., National Research Center, Dokki, Cairo, Egypt

2- Ornamental Plant and Woody Trees Dep., National Research Center, Dokki, Cairo, Egypt

aE mail: magdyattia@hotmail.com

(Received April 16, 2005)

(Accepted May16, 2005) 


\section{Attia and Rawia Eid}

$\mathrm{AMFT}=\mathrm{AMF}$ inoculation at transplanting stage; $\mathrm{AMFC}=$ direct $\mathrm{AMF}$ inoculation to cuttings.

*Significant at $5 \%$. ** Significant at $1 \%$. 
Arab Univ. J. Agric. Sci., Ain Shams Univ., Cairo, 13(3), 677 - 688, 2005

sources (Attia, 1999). As shown in Table (5), significant macronutrient concentration in leaves was observed in AMFC treatment compared with control plants. On the other hand, micronutrient concentration was considerably increased in AMFC and AMFT treatments compared with control. We found that rooting rate was $77 \%$ in non-mycorrhizal treatment, whereas it was $99 \%$ in AMF treatment at transplanting stage (Table, 2). Plant growth in AMF treatment increased by more than twice than those in non-AMF treatment. After transplanting, the fresh and dry root weights were greatest in AMFC treatment followed by AMFT treatment, and then control treatment (Table, 3). This result clearly indicate that early AMF inoculation (directly to cuttings) was most advantageous for the growth of chrysanthemum. Attia et al (2004) reported that early infection by VAM fungi was very important for growth and yield response of mycorrhizal plants, especially in short-duration crops. Colonization rate was $76.42 \%$ when AMF inoculation was performed directly to cuttings and $64.24 \%$ when AMF inoculation was done at transplanting. As shown in Fig. (1) and Table, (4), AMFC treatment significantly shortened flowering time and increased flower quality. This suggests that early colonization of young plant roots improved plant root surface absorbing hence nutrients more efficiently, thereby resulting in better plant performance.

Plants inoculated with AMF flowered earlier than the uninoculated controls. Chry $\square$ santhemum AMFC and AMFT treatments flowered 98 and 104 days after transplanting, respectively, whereas plants in control treatments took 112 days to flower. Similar results have been reported in number of ornamental plants. Gaur and Adholeya (2000) reported that inoculated Callistephus chinensis flowered 27 days after transplanting, whereas the uninoculated plants took 22 days longer. Also, Impatiens balsamia flowered at 37 days, which was 16 days earlier than uninoculated plants and those of Petunia hybrida flowered after 29 days, 12 days ahead of the uninoculated plants.

Fresh weight, width and height of flowers in AMFC and AMFT treatments were generally higher than those in control treatment. Gaur and Adholeya (2000) reported that mycorrhizal inoculation of seedlings led to marked improvement in both reproductive (number of flowers) and vegetative (dry matter) phase of the ornamental plants. The highest fresh weight, width and height of flowers in AMFC treatment confirmed the result of Monticelli et al (2000) that early AMF inoculation significantly increased plant growth compared with applying mycorrhizal inoculation at the transplanting stage.

As shown in our results, AMF inoculation is a vital factor for enhancing

1- Agric Microbiology Dep., National Research Center, Dokki, Cairo, Egypt

2- Ornamental Plant and Woody Trees Dep., National Research Center, Dokki, Cairo, Egypt

${ }^{a} E$ mail: magdyattia@hotmail.com

(Received April 16, 2005)

(Accepted May16, 2005) 
plant growth; however, the timing of inoculation should be considered. With better nutrient concentrations and early flowering resulting from directly inoculated cuttings, the expenses of fertilizers could be reduced and time of production will be saved, which translates to higher profits for farmers.

\section{REFERENCES}

\begin{abstract}
Abdalla, M.E. and G.M. Abdel-Fattah (2000). Influence of the endomycorrhizal fungus Glomus mosseae on the development of peanut pod rot disease in Egypt. Mycorrhiza 10: 29-35.
\end{abstract}

Attia, M. (1999). The efficiency improvements of mineral fertilizers used and maize yield by arbuscular mycorrhizal funfi and plant growthpromoting rhizobacteria. Annals Agric. Sci, AinShams Univ. Cairo, 44: 41-53. Attia M.; Hoda A. Hamed and Azza Sh. Turky (2004). Influence of root colonization with Bacillus subtilis, Trichoderma harzianum and arbuscular mycorrhizae on promoting tomato seedling, yield and protection against Fusarium crown and root rot. Bull. NRC, Egypt, 29: 347-360.

Azcon-Aguilar, C.; I.G. Padilla; C.L. Encina; R. Azcon and J.M. Barea (1996). Arbuscular mycorrhizal inoculation enhances plant growth and changes root system morphology in micropropagated Annona cherimola Mill. Agronomie 16: 647-652.

Badr El-Din S.M.S. and M. Attia (2003). Rationalization of irrigation water of maize plants by inoculation with arbuscular mycorrhizal (AM) fungi. Egypt. J. Microbiol. 38:323-336. Badr El-Din S.M.S.; M. Attia and S.A. Abo-Sedera (1999). Evaluation of several substrates for mass multiplication of arbuscular mycorrhizal (AM) fungi grown on onion. Egypt. J. Microbiol. 34:57-65.

Gaur, A. and A. Adholeya (2000). Growth and flowering in Petunia hybrida, Callistephus chinensis and Impatiens balsamina inoculated with mixed AM inocula or chemical fertilizers in a soil of low P fertility. Scientia Hort. 84: 151-162.

Hoagland, D.R. and D.I. Arnon (1938). The Water Culture Method for Growing Plants Without Soil. College of Agriculture. Agr. Expt. Stat. Circ. p. 347, University of California, Berkely. Jones Jr., J.B.; B. Wolf and H.A. Mills (1991). Plant Analysis Handbook, Micro-Macro Publishing. Dekker, New York, pp. 195-203.

Kim, K.Y.; D. Jordan and G.A. McDonald (1998). Effect of phosphatesolubilizing bacteria and vesicular $\square$ arbusculamycorrhizae on tomato growth and soil microbial activity. Biol. Fertil.

Soils 26: 79-87.

McGonigle, T.P.; M.H. Miller; D.G. Evans; G.L. Fairchild and J.A. Swan. (1990). A new method which gives an objective measure of colonization of roots by vesicular-arbuscular mycorrhizal fungi. New Phytol. 115: 495-501.

Monticelli, S.; G. Puppi and C.

Damiano (2000). Effects of in vivo mycorrhizal on micropropagated fruit tree rootstocks. Appl. Soil Ecol. 15: 105111.

SAS Institute, (1990). SAS User Guide, version 6.08. SAS Institute Inc. SAS Circle. Box 8000, Cary, NC $27515 \square 800010$.

Subhan, S.; P. Sharmila and P. Pardha Saradhi (1998). Glomus fasciculatum alleviates transplantation shock of 
Inoculation effect with arbuscular mycorrhizal fungi on chrysanthemum

micropropagated Sesbania sesban. Plant

Cell Rep. 17: 268-272.

Uosukainen, M. and M. Vestberg

(1994). Effect of inoculation with

arbuscular mycorrhizas on rooting, weaning and subsequent growth of micropropagated Malus (L.) Moench.

Agric. Sci. Finland 3: 269-279.
Yano-Melo, A.M.; O.J. Saggin Jr.; J.M. Lima-Filho; N.F. Melo and L. Maia. (1999). Effect of arbuscular mycorrhizal fungi on the acclimatization of micropropagated banana plantlets. Mycorrhiza 9: 119-123. 
Arab Univ. J. Agric. Sci., Ain Shams Univ., Cairo, 13(3), 677 - 688, 2005

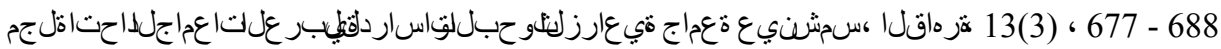
، 2005

\section{]44[}

\section{ةريهزتوومنل|ىلإيروكيثيل|يرطفيقيقلتلنايقوريثيثأت

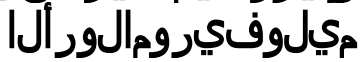

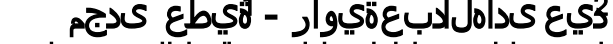

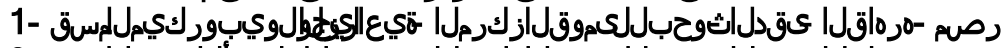

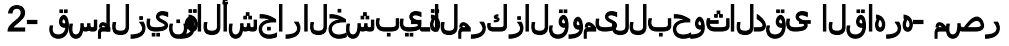

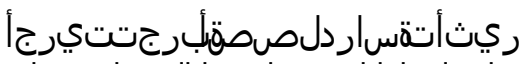

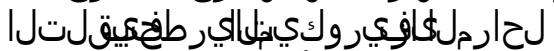

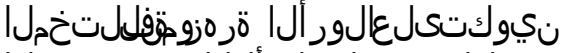
متالقليزيقحت

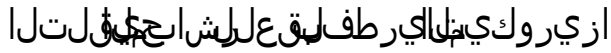

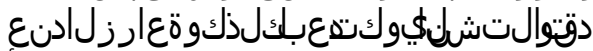

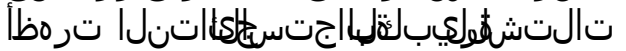

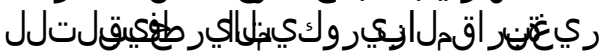

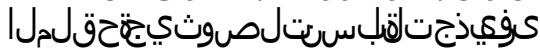
|

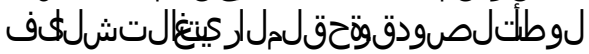

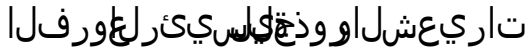

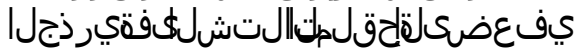

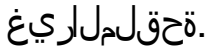

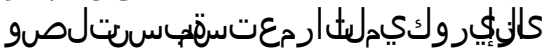

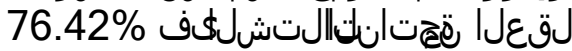

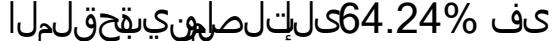

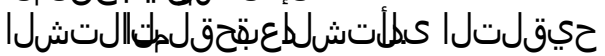

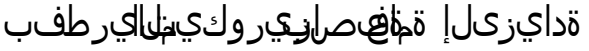

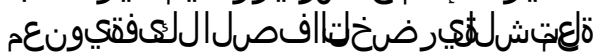

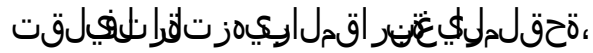

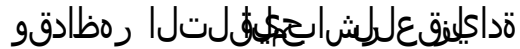

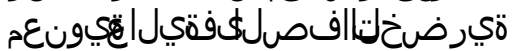

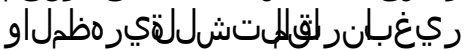

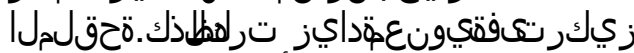

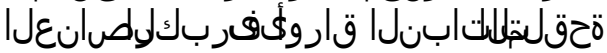

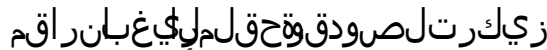

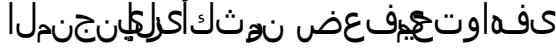

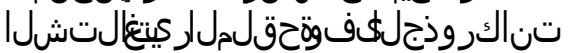

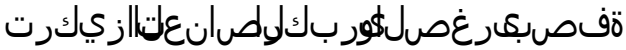

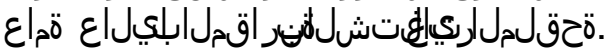

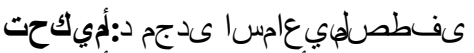

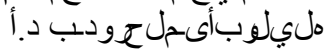

1- Agric Microbiology Dep., National Research Center, Dokki, Cairo, Egypt

2- Ornamental Plant and Woody Trees Dep., National Research Center, Dokki, Cairo, Egypt

${ }^{a}$ E mail: magdyattia@hotmail.com

(Received April 16, 2005)

(Accepted May16, 2005) 
Arab Univ. J. Agric. Sci., Ain Shams Univ., Cairo, 13(3), 677 - 688, 2005

1- Agric Microbiology Dep., National Research Center, Dokki, Cairo, Egypt

2- Ornamental Plant and Woody Trees Dep., National Research Center, Dokki, Cairo, Egypt

${ }^{a}$ E mail: magdyattia@hotmail.com

(Received April 16, 2005)

(Accepted May16, 2005) 